\title{
Wilms Tumor Protein
}

National Cancer Institute

\section{Source}

National Cancer Institute. Wilms Tumor Protein. NCI Thesaurus. Code C17549.

Wilms tumor protein $(449 \mathrm{aa}, \sim 49 \mathrm{kDa}$ ) is encoded by the human WT 1 gene. This protein is involved in transcriptional regulation, embryonic morphogenesis and in both tumor suppression and tumorigenesis. 